\title{
Around the Bush Yet Again: Reflection on Reckless Vectors, Past and Present
}

\author{
Ivan Emke
}

Disease is an analytic prism for cultural understanding. Entire mythologies build up, not only about a disease itself, but about the individuals bearing the disease. Social images, stereotypes, and official fictions come to be perpetuated by the media as the facts of the disease. . . . Diseases of no known cause or cure, especially, strike at the very depths of our fears. (Payne \& Risch, 1984, p. 17)

We sometimes forget that changes in attitudes and behaviors in response to diseases are, on a societal level, lamentably slow and fragmented. Surrounded by people who think similarly to ourselves, we may become convinced that certain battles are won, that particular unfortunate linkages and attitudes have finally been banished. Then, something happens to wrench us back into the awareness that there are important struggles still to be won. This is precisely what happened to me when I read through the papers in Reckless Vectors. I developed a sense of almost a déjà vu-that these papers related to cases that were marked by the cultural logic of a particular time. Some of them, such as James Miller's (2005) treatise on Charles Ssenyonga or Cindy Patton's (2005) narrative on Edward Savitz, seemed to arise from earlier days in our understanding of HIV and AIDS, and I felt that by now these were to be read as instructive historical examples of the creation and characterization of folk devils-instructive, yes, but nevertheless historical.

Complacency can arise from such a perspective. The danger can be seen as no longer imminent, and the task can become only to critique the misadventures of the past. I had convinced myself that the type of cultural and social responses to HIV that Mary Petty's (2005) article outlined were no longer operative. Inoculated by this false sense of security, I was leafing through The Western Star, our local newspaper here in Western Newfoundland. In Canada, there is continuing discussion of the federal government's plan to recognize same-sex marriage. (Same-sex marriages had already been taking place legally in many provinces, but the federal government had yet to pass official legislation to acknowledge this change.) This legal development provided an open space for those who were uncomfortable with homosexuality to use whatever forms of argumentation they wished (no matter how ill-informed or damaging) to oppose it. Indeed, it offered a platform for those who wished to continue to argue that the spread of AIDS was the fault of gay men and that casual contact with a reckless vector (although they do not use that term) could be deadly.

To pick up the story again, I was reading through The Western Star when I came across a letter from a writer who opined:

Why don't the perverting homosexuals, who are already in our schools promoting the homosexual lifestyle, tell students about people like Kimberly Bergalis, 23, of Fort Pierce, Florida? She contacted AIDS from her bisexual dentist and this beautiful woman, in the prime of her life, is now dead. (Boyle, 2005, p. 7)

Later, this writer offered the following epidemiological advice: "It is possible to catch AIDS from a dental visit, heavy kissing, playing sports, in a fist fight or from a mosquito bite" (p. 7). Reading this letter gave me "the shock of the old." The arguments about homosexuality as repository of infection, and about how certain gay men can be dangerous infectors, reminded me of similar pronouncements I had read 20 years ago during the first wave of panic about the AIDS epidemic.

And so I concluded that we have not moved as far as I had hoped. The articles in Reckless Vectors, which I had first read with the luxury of hindsight, have been revealed 
as struggles in progress, rather than struggles won. The scoreboard is not yet marked. Yet, that may be no real surprise. After all, the stigmatizing of certain persons who are ill has been with us for some time. A generation or two of social scientists ago, Talcott Parsons (1951) talked about the ill taking on a sick role, wherein people are not blamed for their illness. They experience some benefits (if you will) of sickness, such as not being considered responsible for their illness and not being required to fulfill all of their social duties; however, the assumptions that people will try to get better and that they will cooperate with their doctors are also associated with that role. Without these behaviors, the benefits are gone, and the identity as a sick person is no longer protected. In the set of papers in Reckless Vectors, we meet a number of individuals who did not cooperate with medical advice and who suffered similar consequences to their identity, including Christopher Truscott of New Zealand (in MacDonald and Worth's, 2005, article), Charles Ssenyonga of Canada (from Miller's, 2005, piece), and Gregory Smith (in Petty's, 2005, discussion).

The articles in this issue triggered in me a memory of the early media representations of other dangerous vectors for transmission of HIV. For example, one of the common terms for PWAs in the early days of the epidemic in Canada was carrier, and the use of this term legitimized a particular set of solutions for limiting the spread of HIV - specifically, the marking and isolating of infected bodies. Language is not neutral. Words bear the marks of the interests of particular discourses and so does the term carrier. The word itself has a variety of meanings, including its reference in medicine to a person who harbors an organism or virus that can be transmitted to others but who typically bears no symptoms of disease. Typhoid Mary is probably the most famous model for such a carrier in North America (Leavitt, 1996). Through her work as a cook, she was viewed as being partly responsible for a typhoid outbreak in New York City in the early 1900s. After being tracked down, she was quarantined, and she remained forcibly isolated until her death in 1938. A carrier may also have a legal status that, depending on the disease, can allow medical authorities to demand that the carrier be quarantined. The carrier's body, as a repository of infection, will therefore be incarcerated. Finally, this term implies some volition in the transmission of disease, and its use opens a space for legitimating forcible containment of the carrier.

In the early days of HTLV-III (Remember this term?), five words were generally used in the Canadian press to designate PWAs: victim, case, sufferer, patient, and carrier. And sometimes several of them were used interchangeably, although it was very rare that carriers were also described as victims. The latter were viewed as not being responsible for their infection, whereas use of the former term implied some volition and personal responsibility. As is pointed out in the introduction to this special issue (Worth, Patton, \& Goldstein, 2005), there are calculations that are made to determine when some PWAs are seen as innocent, whereas others are considered culpable for contracting the virus. Thus, carrier can refer to specific PWAs and victim can refer to others, depending on the circumstances of their viral transmission. As such, I imagine that carrier was sometimes decoded as a euphemism for guilty.

To refer to carrier implies that something is transported from somewhere to someplace else (or from someone to someone else). One Canadian newsmagazine, Alberta Report, was very explicit about its vision of what had been carried and by whom. A November 1985 feature story (Weatherbe) in the magazine on "Alberta's AIDS Menace" stated: "What was once seen as a 'gay plague' is now perceived as a threat to anyone who comes within spitting distance of a homosexual.... AIDS has emerged from the homosexual closet to haunt the world" (p. 46).

Here, carriers were seen to cross a boundary that separated the homosexual closet from the heterosexual world. (Bisexuals, who were seen as already straddling this fragile boundary, were thus believed to be the most dangerous carriers of all.) In March 1987, Alberta Report publisher Ted Byfield, in a column devoted largely to denouncing the power of the gay-rights groups, wrote: "Every effort is being made to divert attention from the major risk group [gay men] involved in conveying the epidemic" (p. 52). Byfield further charged that gays, having "offended nature" and paid the price by getting AIDS, were now "conveying" it to the heterosexual community. Here the term carrier took on a sense of conscious conspiracy, of an epic struggle between us and them.

Thus, carriers not only transported a virus but also harbored a danger to others. In order to be a threat, they had to have access to a repository of infection. A 1987 article (Forsyth) in Equinox, a Canadian nature magazine, called "The Plague Within," argued that:

In North America, it is true that the HIV reservoir is now populated by people from well-defined risk groups. Homosexual males constitute about 70 percent of the reservoir, with prostitutes and intravenous drug users being the next largest group. Heterosexuals comprise only 4 to 8 percent-the so-called nonrisk cases. (pp. 109-110)

According to Webster's Collegiate Dictionary (Merriam, 1976), one meaning of reservoir is "an organism in which a parasite that is pathogenic for some other species lives 
and multiplies without damaging its host" (p. 730). The claim that the gay community represented such a reservoir implied that there might be something intrinsic to this community that produced the virus in the first place. There was also a touch of relief in the article, arising from the belief that the disease was still limited to this reservoir. However, there were also disconcerting signs that the disease was being spread to others.

A major result of the panic about carriers in the $1980 \mathrm{~s}$ was concern about those infected with the virus who might act as irresponsible agents. For example, prostitutes were singled out as a group of folk devils who could be responsible for the spread of the disease from so-called high-risk groups to the general population (Cohen, 1989). The widely reported case of an Ottawa prostitute who continued to work even though she was HIV-infected (MacLeod, 1986) was cited as evidence of this possibility. The fact that she regularly used condoms (except when men tried to rape her) did not dispel this myth. If carriers acted inappropriately, then the use of legal sanctions against them could be seen to be justified as a way of protecting the general public. For example, the use of the police to control carriers was legitimated in the coverage of a Halifax man who was accused of "knowingly" spreading the disease. The September 19, 1988, Halifax Chronicle-Herald announced in bold letters on page 1, "AIDS FIEND STRIKES AGAIN" (Madill, 1988), and the story's subheading was "Bisexual carrier 'a very serious health hazard.' " The Nova Scotia Health Minister, Joel Matheson, was quoted in the story as saying that "the police are the appropriate agency to handle the situation" (p. 1). There is a note of urgency in his statement that the legal apparatus must be mobilized in order to protect society. Throughout the article, the man was referred to as a "carrier." The Globe \& Mail, our national newspaper of record in Canada, referred to this same man as an "AIDS-virus carrier" (Emerson, 1988), and the Toronto Star used the term "AIDS suspect" ("Canada-wide Manhunt," 1988). Generally, such coverage reinforced the beliefs that carriers represented a special threat to the social fabric and that their control was the responsibility of the police.

This particular carrier represented a condensed image-he was a bisexual prostitute who had allegedly infected a pregnant woman and possibly her fetus. Thus, a number of moral panics came together in this one incident-the boundary-straddling bisexual, the diseased prostitute, and the criminal behavior of the carrier who threatened the defenseless general public. For those who compared AIDS to the bubonic plague, the image of a carrier infecting a fetus contained some metaphoric currency. Within this metaphor, civilization itself was threatened. According to this reasoning, dramatic measures were required to protect society, and the introduction of legal discourse was thereby legitimated. A similar situation involved a Calgary man who was charged with having "condomless sex with two women" (Heaton, 1989, p. 30). His photograph was released by the police department and published in the press. In addition, the police set up a special hotline number to be used by anyone who knew the accused or thought they had had sex with him. In effect, this vastly extended police surveillance of the man.

The practice of stigmatizing whole groups of people as carriers has its own long tradition. For example, during the time of the bubonic plague in France in the fourteenth century, Jews were accused of being responsible for the disease. They were called "well poisoners," using the metaphor that they had infected the sources of drinking water with the plague (Tuchman, 1978). In this case, the people were looking for a human agent to hold responsible for these events. Instead, blaming Jews became a justification for lynching and burning them in order to punish the misperceived causes of the plague. Entire communities of Jews were murdered in the German cities of Freiburg, Augsburg, Munich, and Mainz in spite of the epidemiological reality that the plague affected the Jews as much as the Gentiles and that it spread in areas where there were no Jews at all. As a result, for the Jews of Germany and western Europe, the accusations, attacks, and pogroms of their former neighbors were at least as fatal as the bubonic plague itself.

The accusation of well-poisoning was used at least as early as the plague of Athens in 430 B.C., when it was applied against the Athenian rivals, the Peloponnesians (Thucydides, 1989). Could it be said that the "well poisoners" of our own age are the carriers of HIV? How else can one account, except as a result of this primitive displacement of hostility, for those who believe AIDS originated in the gay community as a direct result of an imagined gay lifestyle? How else can we explain those who claim that it is gay men who endangered the nation's blood supply? Perhaps the blood supply, a national system of blood collection and distribution, is perceived by these individuals to be a well that has been poisoned in some very concrete, as well as metaphoric, sense.

The fourteenth-century outbreak of the bubonic plague was seen as "God's terminal disappointment in his creature" and as "a scourge so sweeping and unsparing without any visible cause [that it] could only be seen as Divine punishment" (Tuchman, 1978, p. 107). This explanation resulted in the enactment of certain types of solutions, such as the penitent processions authorized by the Pope. These processions, some of which lasted as long 
as three days, featured large groups of people clothed in sackcloth, weeping and tearing at their bodies, whipping themselves, and imploring the mercies of the saints and the intervention of the Virgin that ironically, due to the nature of the processions and the large congregations of penitents, actually helped to further spread the plague.

In a similar manner, some contemporary proposed solutions for the problem of AIDS may lead to the further spread of HIV. Specifically, to construct those who are HIVinfected as a category of folk devils, to then call for measures to mark those who belong within the boundaries of this category, to emphasize their danger to the general population, and finally to legitimize interventions against them by the powers of the state describes one set of solutions to AIDS that are dissected and critiqued in this journal issue.

These are some of the stories that I remembered as I read the articles in Reckless Vectors. They were stories from centuries ago and stories from just a couple of decades ago. But to be more accurate, they are stories that I had almost forgotten. As I read through Reckless Vectors, these stories came back to me, like apparitions of a past I had thought was over. Indeed, the issues discussed in the articles in this special issue must be read not as reflections of the past, but as reminders of current challenges. Indeed, it feels as though we are repeating history and that we are going around the bush yet again. We must gather our wits for the continuing struggle to respond to $\mathrm{HIV}$ in ways that empower PWAs to make effective changes, to educate the HIV-negative on how to protect themselves, and to avoid public health and corrections measures that further stigmatize those with HIV.

\section{References}

Boyle, E. (2005, March 12). Why is telling the truth promoting hatred? [Letter to the editor]. The Western Star, p. 7.

Byfield, T. (1987, March 30). AIDS may not be 'the plague' but there are some similarities. Alberta Report, p. 52.

Canada-wide manhunt begins for AIDS suspect from Halifax. (1988, September 25). Toronto Star, p. A4.

Cohen, J. (1989, January). Overstating the risk of AIDS: Scapegoating prostitutes. Focus, pp. 1-2.

Emerson, G. (1988, September 19). Search for AIDS-virus carrier raises legal, ethical questions. Globe and Mail, pp. A1, A5.

Forsyth, A. (1987, Nov/Dec). The plague within. Equinox, pp. 88-112.
Heaton, G. (1989, April 24). Dangerous Liaisons. Alberta Report, pp. 30-32.

Koch, G., \& Fay, O. (1987, September 14). The ethics of AIDS. Alberta Report, p. 33.

Leavitt, J. (1996). Typhoid Mary. Boston: Beacon Press.

MacDonald, A., \& Worth, H. (2005). Mad and bad: HIV infection, mental illness, intellectual disability, and the law. Sexuality Research \& Social Policy: Journal of NSRC, 2(2), 51-62.

MacLeod, I. (1986, May 10). Hooker is AIDS carrier, doctors warn customers. Ottawa Citizen, pp. A1, A15.

Madill, D. (1988, September 19). AIDS fiend strikes again. Halifax Chronicle-Herald, pp. 1-2.

Merriam, G. \& C., and Company (1976). Webster's seventh new collegiate dictionary. Springfield, IL: G. \& C. Merriam and Company.

Miller, J. (2005). African immigrant damnation syndrome: The case of Charles Ssenyonga. Sexuality Research \& Social Policy: Journal of NSRC, 2(2), 31-50.

Parsons, T. (1951). The social system. New York: Free Press.

Patton, C. (2005). Outlaw territory: Criminality, neighborhoods, and the Edward Savitz case. Sexuality Research \& Social Policy: Journal of NSRC, 2(2), 63-75.

Payne, K. W., \& Risch, S. J. (1984, September). The politics of AIDS. Science for the People, pp. 17-24.

Petty, M. (2005). Social responses to HIV: Fearing the outlaw. Sexuality Research \& Social Policy: Journal of NSRC, 2(2), 76-88.

Stocking, S. H., \& Gross, P. H. (1989, Spring). Understanding errors, biases that can affect journalists. Journalism Educator, 44(1), 4-11.

Thucydides. (1989). The history of the Peloponnesian War (David Greene, Trans.). Chicago: University of Chicago Press. (Original work published 431-411 BCE)

Tuchman, B. W. (1978). A distant mirror: The calamitous 14th century. New York: Alfred A. Knopf.

Weatherbe, S. (1985, November 25). Alberta's AIDS menace. Alberta Report, pp. 46-51.

Worth, H., Patton, C., \& Goldstein, D. (2005). Introduction to reckless vectors: The infecting "Other" in HIV/AIDS law. Sexuality Research \& Social Policy: Journal of NSRC, 2(2), 3-14. 